\title{
ACMEOLOGICAL FORMATION OF PROFESSIONAL COMPETENCE OF FUTURE TEACHERS OF NATURAL SUBJECTS IN TERMS OF PROBLEM-CONTEXTUAL EDUCATION
}

\section{Ivanytsky O. I.}

\section{INTRODUCTION}

According to the technological approach of V. Bespalko ${ }^{1}$, the pedagogical system should be given a new technological orientation, such as preliminary design of the learning process with an emphasis on the educational and cognitive activity of the student, the diagnostic of the target component and the associated objectivity of monitoring the results. In this regard, one of the most important areas of research in the field of higher pedagogical education is the development of technological characteristics of the teacher, ways, means and forms of development of students' professional skills. N. Kuzmina, carefully analyzed the activity of the teacher, identified three interrelated components in the structure of pedagogical activity: constructive, organizational and communicative ${ }^{2}$. Constructive activity is divided into constructive and meaningful (selection and composition of educational material, planning and construction of the learning process), constructive and operational (planning their actions and actions of students) and constructive and material (design of educational and material base of the pedagogical process). Organizational (management) activity involves the implementation of actions aimed at the inclusion of students in various activities, the creation of a team and the organization of joint activities. Communicative activity is aimed at establishing pedagogically appropriate relations of teachers with students, other teachers of the school, members of the public, parents. The ability to effectively use these components is a professional readiness for teaching.

${ }^{1}$ Беспалько В. П. Слагаемые педагогической технологии. Москва : Педагогика, 1989. $302 \mathrm{c}$.

${ }^{2}$ Кузьмина Н. В. Предмет акмеологии. Санкт-Петербург : Питер, 1995. 158 с. 
In modern conditions of modernization of higher education in Ukraine the readiness for pedagogical activity is provided by formation of a complex of General and professional competences. An important component of the teacher's professional readiness is the ability to implement a particular learning technology. After all, the technology of training contains a coordinated combination of forms, methods and means of training, so and its design and implementation require future teachers of natural science subjects to master groups of competencies indicated by descriptors: knowledge, skills, communication, autonomy and responsibility ${ }^{3}$. The formation of these competencies is based on the study of the features of the process of teaching natural subjects as a link in the pedagogical process, teaching its construction and driving. Under the concept of technology of teaching natural subjects we understand a systematic way of organizing the subject-equitable activity of teachers and students, for which the implementation of the diagnostic goal is achieved reproducible under these conditions, a consistent combination of organizational forms, methods and means of teaching natural subjects. The problem of educational technology in the high school has two important aspects. The first of them is the implementation of learning technologies in the classroom directly by the teacher. The second aspect is the special training of future teachers of natural science subjects for the implementation of learning technologies in their further independent work in the high school. This training is comprehensive, systematic and based on a systematic approach to the learning process on the basis of a common methodology of targeting. The application of the system-activity approach to the training of future teachers of natural subjects in the high education has its own specifical features which are determined by the characteristics of natural subjects as a science and educational subject. They are primarily determined by the content of natural objects and the structure of their study, model and symbolic representation of knowledge, a significant proportion of demonstration and frontal experiment, high emotionality of study, opportunities for the formation of cognitive interest.

${ }^{3}$ Іваницький О. I. Формування фахових компетентностей майбутніх учителів фізики в процесі самостійної роботи. Вісник Запорізького національного університету. Педагогічні науки. Вип. 1 (30). Запоріжжя : ЗНУ, 2018. С. 107-113. 


\section{Professional training of the future teacher of natural subjects as a system}

According to the draft standard of higher education of Ukraine of the first (bachelor) level of high education specialty 014 Secondary education (subject specialties) (one of the developers of which is the author of this section of the monograph) identified General and professional competence common to the all subject specialties ${ }^{4}$ :

General competences $(G C)$

$\mathrm{GC1}$. An ability to realize your rights and obligations as a member of society, to realize the values of civil (free democratic) society, the rule of law, human rights and freedoms and citizen of Ukraine.

GC2. The ability to generalize the main categories of the subject area in the context of the historical process.

GC3. The ability to learn and acquire modern knowledge.

GC4. The ability to work in a team.

GC5. The ability to communicate in the state language both orally and in writing.

GC6. The ability to communicate in a foreign language.

GC7. The ability to apply knowledge in practical situations.

GC8. Skills in the using of information and communication technologies.

GC9. The ability to act on ethical grounds (motives).

GC10. The ability to adapt and act in a new situation.

Professional competences common to all subject specialties (PC)

PC 1. The ability to form students' key and subject competencies and implementation of interdisciplinary connections.

PC 2. Knowledge of the basics of goal setting, planning and design of the learning process of students.

PC 3. The ability to exercise objective control and evaluation of the level of educational achievements of students.

PC 4. The ability to find effective ways to motivate the child to selfdevelopment (self-determination, interest, conscious attitude to learning).

${ }^{4}$ Іваницький О. І. Формування фахових компетентностей майбутніх учителів фізики в процесі самостійної роботи. Вісник Запорізького національного університету. Педагогічні науки. Вип. 1 (30). Запоріжжя : ЗНУ, 2018. С. 107-113. 
PC 5. The ensuring the protection of life and health of students (including those with special needs), their physical activity in the educational process and extracurricular activities.

PC 6. The ability to carry out education in the classroom and in extracurricular activities, to perform pedagogical support of the processes of socialization of students and formation of their culture.

PC 7. The ability to critical analysis, diagnosis and correction of own pedagogical activity, evaluation of pedagogical experience.

This is reflected in the educational and professional training programs for bachelors and masters of subject specialties 014.08 Secondary education (Physics), 014.05 Secondary education (Biology), 014.06 Secondary education (Chemistry), 014.07 Secondary education (Geography), 014.15 Secondary education (Natural Sciences). It gives reason to talk about the General approaches and features of the training of future teachers of these natural subjects.

The difficulty of the process of training teachers of natural subjects to the implement innovative learning technologies is primarily due to the variability of these technologies in the training of natural subjects ${ }^{5}$. How to help, on the one hand, the teacher to act consciously and optimally in different situations of teaching natural subjects in secondary education, on the other hand, to prepare future teachers of natural subjects in the high education institutions for the using of variable technologies of different levels in professional activities? The style of professional activity of the future teacher of natural subjects can be considered, in general, as a rather persistent individual a kind of activity organization which is created as a result of the student's efforts to achieve the best learning goals under these conditions. However, the goals and conditions of teaching natural subjects are characterized by certain uniqueness, repeatability, resulting in the appearing of validity, the relative stability of individual style of activity of each student (future teachers of natural subjects) and allow to talk about technologic training of future teachers of natural science subjects. One of the productive directions of solving this problem is the allocation of invariant and variable parts not only in a particular technology of teaching natural science subjects, but also in the activities of the teacher of natural subjects for the design and

5 Справочник учителя физики. Приложение к сборнику «Проблемы формирования теоретических обобщений и вариативных технологий обучения физике». Вып. 1. Москва : МПУ, 1999. 59 с. 
implementation of these technologies ${ }^{6}$. But firstly you need select the generalized invariant actions of the teachers of natural subjects which is the sequence of specific steps required in the scopes of any learning technology of natural science subjects. This is a base in the work of the teacher, a generalized algorithmic instruction, performing which the teacher will be able to find within each stage options for organizing educational interactions, due to both the content of the educational material and the learning objectives in the specific conditions of the educational process. Thus, the sequence of stages of the teacher's activity is an invariant, and the operational composition of these stages is a variable component which is designed by the teacher in accordance with the conditions of training. Let's imagine these steps in their logical sequence:

1. Scientific and methodological analysis of educational material, its structuring and selection of elements of assimilation, the construction of iconic models, such as structural and logical schemes (SLS) of varying degrees of generality, the allocation of scientific and methodological ideas.

2. A goal setting - selection and formulation of the system of goals of educational activities in a diagnostic way.

3. Modelling activities of teachers and students on the basis of the allocation of stages of the study of this piece of educational material on natural subjects.

4. Construction of a system of didactic materials necessary for coordinated feedback in the systems of "teacher of natural subjects student" and "student - class team" to ensure effective and efficient independent work of students to control, self-control and correction of the educational trajectory of the student on the basis of diagnostic of the goal setting and its hierarchy.

5. A planning of educational experiment system (demonstration, front, workshop, individual experimental tasks).

6. The planning of work with educational tasks.

7. Construction of the technological line of study of the topic (creation of a technological map of the topic) - a sequence of training

${ }^{6}$ Іваницький О. I. Сучасні технології навчання фізики у середній школі [Монографія]. Запоріжжя : Прем’єр, 2001. 266 с.; Іваницький О. І. Інноваційні технології навчання фізики. Навчальний посібник. Запоріжжя : Диво, 2007. 99 с.; Іваницький О. І., Ткаченко С. П. Технології навчання фізики. Навчальний посібник. Запоріжжя: ЗНУ, 2010. 252 с. 
sessions of various forms in accordance with the specific conditions and objectives of training.

The stages of activity of the teacher in their logical sequence are allocated the technology of design of its activity which can be called "didactic technology". Its development by the teacher of natural subjects will allow him to work consciously and effectively in variable conditions of training of natural subjects in modern secondary school. On the other hand, this invariant, due to its universality, is a reference point both in the preparation of the future teacher of natural subjects for the using of innovative learning technologies, and in the development of criteria for the effectiveness and efficiency of this training. Guided by the general scientific theory about the function of social systems, we give the different approaches to the study of the functions of professional training of teachers in the theory of high pedagogical education, we consider the training of teachers of natural subjects at the university as a complex dynamic system which is inherent in certain functions that ensure its sustainable existence. These functions can be divided into two groups: internal (educational, developmental, educational), reflecting the possibilities of the system of vocational training, the relationship and interdependence of its individual components, and external (coordinating and integrating), reflecting the ratio of professional training of teachers of natural subjects to the components of the education system as a whole, their interaction and natural connections. In this regard, professional and pedagogical training of teachers of natural science subjects in higher education is a multi-faceted system that combines a relatively independent, but interrelated and interdependent system of training: special-scientific, psychological, pedagogical and methodological. For the effective functioning of the school, professional and pedagogical training of a specialist, among other things, should have a prognostic, leading character, be focused on the school of the future. Special scientific training of the future teacher of natural subjects is aimed at mastering by him deep and versatile knowledge and skills from the main subject, knowledge of the content and methods of the natural science subject as a science, relevant practical skills and abilities. Psychological and pedagogical training provides students with knowledge on the basics of pedagogy, psychology, age physiology and school hygiene, inclusive education, creates the basis for comprehensive methodological training of future teachers of natural subjects. 
Methodical training of the teacher is aimed at mastering the relevant knowledge, skills and abilities in the theory and methodology of teaching a natural science subject ${ }^{7}$.

The basis of methodological training are the following factors:

1) the study of methods of teaching natural subjects is preceded by the study of students of the general course of natural subjects. It means that future teachers have a systematic knowledge of the main sections of the course of natural subjects as a science;

2) courses of pedagogy and psychology have studied;

3) the passive pedagogical practice is carried out, and therefore the corresponding motivation of studying of a course of a technique of training of a natural-science subject is provided.

Due to these factors, in the process of studying the methods of teaching a natural subject it is necessary to implement a next program of action:

- to ensure the adaptation of student knowledge obtained during the study of the university course of a natural subject before the school course;

- to carry out a psychological reorientation of the educational orientation of students, putting at the forefront is not gaining knowledge but and the formation of the ability to give the knowledge to others;

- to implement the integrative content of the method of teaching a natural science subject as an applied didactics which uses the achievements of pedagogical psychology, pedagogy and other sciences.

It is necessary to supplement it with special training for the assimilation, use and introduction of new learning technologies to ensure the prognostic nature of the basic training of teachers of natural science subjects. The need for special training of the future teacher of natural subjects is determined by the underlying reasons which, as shown by V. Sergeev and V. Cybulski, caused by a single cognitive mechanisms of decision making ${ }^{8}$. Let's consider the cognitive model of design and selection of technologies for teaching natural subjects (fig. 1), built on

${ }^{7}$ Іваницький О. І. Професійна підготовка майбутнього вчителя фізики в умовах інформаційно-освітнього середовища. Запоріжжя : Запорізький національний університет, 2014. 230 с.

Сергеев В. М., Цыбульский В. Л. Когнитивные механизмы принятия решений: Модель и приложения в политологии и истории. Компьютеры и познание. Москва, 1990. С. 105-124. 
the basis of the general model ${ }^{9}$, as amended in accordance with the specifics of our study. On the basis of this model, we analyze the influence of the subjective factor on the design of technologies for teaching natural subjects. In the diagram 1.1 the development of a technology of training of the teacher of the natural object is showed. Even if he uses a ready-made technological scheme, he still needs to perform the entire cycle of actions presented in the scheme. Objective factors are in this case:

- objectives of the study topics arised the objectives of natural subjects and submitted to the program;

- model of the world, adopted in the study of the school course of a natural a model of the world which is accepted when we are studying subject (we pay your attention that it does not coincide with the model of the world produced by the appropriate science!);

- invariants of activity of the teacher of natural subjects on design of technology of training;

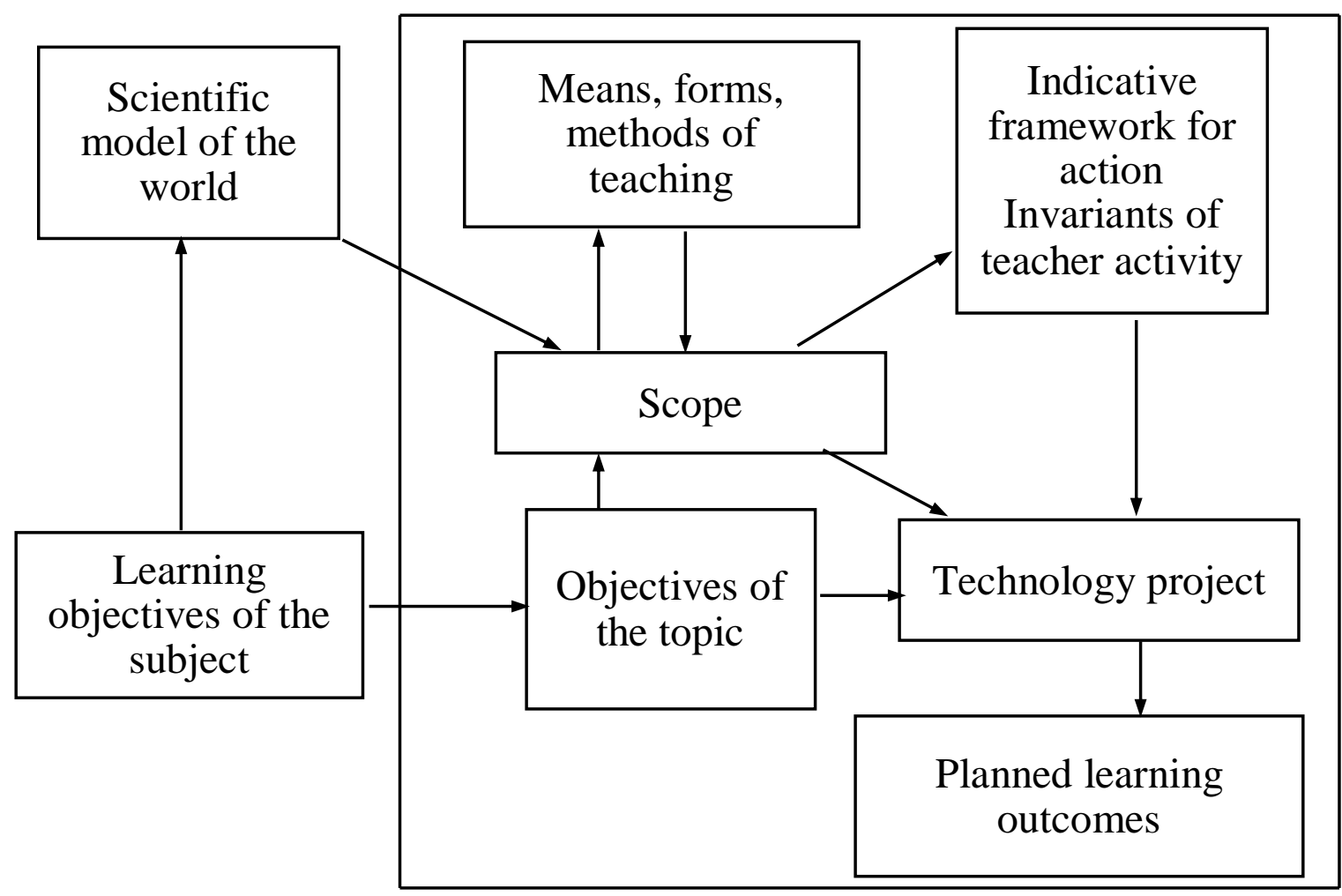

Fig. 1. A cognitive model of design learning technologies natural object

9 Ішмуратов А. Т. Конфлікт і згода. Основи когнітивної теорії конфліктів. Київ : Наукова думка, 1996. 190 с. 
- invariants of the activities of teachers and students when studying the topic;

- means, forms and methods of teaching natural science subjects presented in the block, which we will call "Means". We have introduced the block "Opportunities" as a set of factors that express the subjective characteristics of a particular teacher of natural subjects. In the real process teaching natural subjects in many cases and the model of the world, and the means, and forms, and methods of training depend on the personality of the teacher. Also this unit reflects the cognitive capabilities of students in the class which the teacher must consider. Full devaluation of subjective factors is not possible, but their impact can be reduced and even minimized. Fundamental training of the teacher of natural science subjects is designed to ensure maximum approximation of the subjective model of the world of the objective analogue, psychological, pedagogical and methodological training should provide science based choice and application of forms, methods and means of education. Special training gives future teachers of natural science subjects a reliable indicative framework for action (IFA) in the form of assimilation of invariants of activity of the teacher of natural subjects. The scheme implements the theoretical provisions are considered, postulating the presence at the heart of any decision on the design or use of technologies of teaching natural subjects, three fundamental cognitive blocks: inherent to the teacher "Model of the world", his ideas about his "Means" and "Indicative basis of activity".

On the basis of these three basic units, the technology of teaching natural subjects is eventually built, taking into account the central block of the teacher's "Ability" in relation to this class. Let's emphasize the key position of this unit in the scheme 1. It determines the "freezing" of goals or turning them into planned learning outcomes, for which the development of a specific technology of teaching natural subjects begins. The unit "Opportunities" controls the prerequisites for the creation of learning technology, arising from the comparison of units of "Goals", "Scientific model of the world" with the unit "Means". Types of can be different solutions during the comparing unit "Goals" and "Opportunities", the common is that the unit "technology design" is determined taking into account the unit "Opportunities". Only after that "Goals" actively encourage "IFA" and the formation of projects of learning technologies begins. So, the technology of training is, in fact, 
what we can be done with these conditions of training and available means. The methods of construction of technology of training of natural subjects and their comparison among themselves were studied by means of methods of the system analysis. But from the point of view of cognitology regarding to the technologies of teaching natural subjects, several circumstances can be noted. Firstly, among the invariants of the activity of the teacher of natural subjects there are always invariants of evaluation activity. They include methods of evaluation, taking into account their feasibility, optimality, "correctness", etc. ${ }^{10}$. We can assume that on the basis of such invariants are constructed "meta technology" that allow you to compare learning technology to the natural objects among themselves and to reject some solutions as unproductive. Secondly, the problem is the way of organizing the procedure of choosing the technologies that match the goals with available opportunities $^{11}$.

Empirical observations of students' activities allow us to talk about the existence of individual cognitive styles that reflect the characteristics of these procedures among the different students (teachers of natural subjects). First of all, it should be note the variety of criteria by which the technology can be recognized as acceptable. It can be, for example, a criterion of sufficient proximity when the first available technology is chosen, which "externally" promises success. It can be the criterion of the greatest proximity when from a number of technologies selected the most reliable. Thirdly, the structure of the project of any technology of teaching natural subjects contains an idea of the possibility of its modification in the process of implementation. In this way, the control and evaluation component of the training technology, designed to detect "failures" in time and raise the question of correction, is so important. Fourthly, the choice of technology of teaching natural subjects is affected by the significant influence of stereotypes of the methodical system of work of the teacher, formed at the time of choice. So, the

10 Атаманчук П. С. Інноваційні технології управління навчанням фізики. Кам'янець-Подільський: К-ПДПУ, 1999. 174 с.

${ }^{11}$ Іваницький О. І., Ткаченко С. П. Технології навчання фізики. Навчальний посібник. Запоріжжя: ЗНУ, 2010. 252 с.; Іваницький О. І. Сучасні технології навчання фізики у середній школі [Монографія]. Запоріжжя : Прем'єр, 2001. 266 с.; Іваницький О. І. Інноваційні технології навчання фізики. Навчальний посібник. Запоріжжя : Диво, 2007. 99 с.; Іваницький О. І. Професійна підготовка майбутнього вчителя фізики в умовах інформаційно-освітнього середовища. Запоріжжя : Запорізький національний університет, 2014. 230 с. 
choice of alternatives at the level of projects of technologies of teaching natural subjects is determined, in particular, by: a) the importance of the indicative basis of the teacher of natural subjects, taking into account personal and social experience; b) assessment of the situation and their own funds; c) the type of technology to the goal; d) the pressure of stereotypes of the methodological system of the teacher of natural subjects. In such conditions, the preparation of the future teacher of natural subjects to the using of innovative learning technologies in secondary education should have a special nature and the devaluation of the influence of subjective factors in the block "Opportunities" provide as much as possible and form a stable IFA in the form of invariants of educational activities of teachers of natural subjects and invariant for the design of technologies of teaching natural subjects.

\section{Acmeological approach to professional training of teachers of natural subjects}

Besides the technology of teaching natural science subjects, which are actively used in secondary education, technologies for training teachers of natural subjects in high education are important. These learning technologies have their own specifics and differ from those, involved in high school, technologies primarily focus on a mature person who has a more pronounced motivation for his own learning and development. This motivation is supported by a conscious choice of the area of their professional and personal development. Incentives that provide conscious choice can be social necessity (the need to be competitive in the labour market) and the need to achieve the necessary level of importance of their personality for themselves and for others (I-concept).

The acmeological approach, which has been intensively applied since the 90 s by the acmeological school of N. Kuzmina, has become a productive area of research of teaching technologies in high education institutions ${ }^{12}$. Acmeology (from ancient Greek - "acme" - "the highest point, flowering, maturity, the best time") - a new interdisciplinary field of knowledge in the system of human sciences. It explores the whole person as a subject of creative, educational, professional (including

12 Деркач А. А., Кузьмина Н. В. Акмеология: пути достижения вершин профессионализма. Москва : Просвещение, 1993. 188 с.; Кузьмина Н. В. Предмет акмеологии. Санкт-Петербург : Питер, 1995. 158 с. 
teaching) and managerial activities ${ }^{13}$. Acmeological learning technology is a systematic method of training future specialists in the design, creation and partial verification of highly productive models of author's activity systems $(\mathrm{AAS})^{14}$. So, the subject-methodical training of the teacher of natural subjects includes acmeological technologies of formation of students' professional knowledge and skills in the formulation of the experiment; problem solving; the using of multimedia in the process of teaching natural science subjects; psychological and methodological support of the lesson; management of the motivational side of classes, etc. the basis for the classification of acmeological technologies are $^{15}:$ 1) age factor: $18-25$ years, 26-40 years, 41-50 years, 51 and older (their change depends on the age of both the teacher and the student); 2) direction development (on B. Ananyev): the individual personality, the subject of activity of individuality (the web - from creative potential to creative readiness); 3 ) form of training: individual, group, collective; 4) the level of productivity of activity of the teacher (according to N. Kuzmina): reproductive, adaptive, locally-modeling the knowledge system-knowledge of modeling, system modeling activities; $5)$ the level of educational-cognitive activity of students: the reproduction, partial search, creative search; 6) procedural characteristics of students: modeling, design, construction and others. The concept of acmeological technologies of the professional training acquired its contemporary meaning, too, in the 90 years due to the application of acmeological approach to professional (subjectmethodical) training teachers in higher education. Acmeological technology of vocational training (ATVT) - a set of scientifically based and proven methods, forms and means by which the teacher productively solves acmeological problems of training, education and development of the person of Mature age, contributes to his selfimprovement and professional development ${ }^{16}$. The peculiarity of ATVT, which distinguishes it among the many technologies of vocational

\footnotetext{
${ }^{13}$ Кузьмина Н. В. Предмет акмеологии. Санкт-Петербург : Питер, 1995. 158 с.

14 Энциклопедия профессионального образования: В 3- х т. / Под ред. С. Я. Батышева. Москва : АПО, 1998. 568 с. Т. 1 А-Л.

15 Деркач А. А., Кузьмина Н. В. Акмеология: пути достижения вершин профессионализма. Москва : Просвещение, 1993. 188 с.

${ }^{16}$ Професійна підготовка майбутнього вчителя фізики в умовах інформаційноосвітнього середовища. Запоріжжя : Запорізький національний університет, 2014. 230 с.; Энциклопедия профессионального образования: В 3-х т. / Под ред. С. Я. Батышева. Москва : АПО, 1998. 568 с. Т. 1 А-Л.
} 
training, is that its implementation involves the education of students the desire to learn a profession, this type of activity at the highest level. Regarding the training of the future teacher of natural subjects, it means the development of its methodical system of activity which will further allow to reach the heights of pedagogical skill, the heights of professionalism. Subject-methodical training of teachers of natural science subjects combines acmeological technology with the formation of students' professional knowledge and skills in the formulation of physical experiment, problem solving, the using of multimedia in the learning process, psychological and methodological support of the lesson, management of the motivational side of classes and others. Acmeological technologies of preparation of the future teacher of natural subjects is a system way of training of future specialists to design, creation and partial approbation of elements of methodical system of work of the teacher of natural subjects. The preparation of future teachers of natural science subjects for the using of innovative learning technologies (based on acmeological technologies) involves the design by the student under the guidance of the teacher of theoretical and experimental models of its follow-up as a teacher of natural subjects. Acmeological technologies of training teachers of natural subjects are based on a specific method of acmeology as a science. It is a comparative method of studying different levels of productivity of professional activity and identifying essential features of the highest level. In practice, the design of theoretical and experimental models of future professional activity of the student is based on comparative observation, analysis and evaluation of high, medium and lowproductivity real systems of activity of teachers of natural subjects or students acting as teachers. To do this, the teacher provides students with acmeological methods of studying the level of effectiveness of the results of the teachers of natural science subjects, performance criteria and indicators of development of subjects of the educational process. With the help of this acmeological research tool of professional and pedagogical activity, the student himself reveals the patterns, conditions and factors that stimulate and impede the effective interaction of participants in the educational process. The search for the most suitable forms and ways of effective professional activity is carried out by the student independently and makes a creative decision on what, why and how to involve in their own methodical system of work. As mark 
M. Kolotilova and A. Shmeleva ${ }^{17}$, acmeological learning technologies differ from pedagogical technologies in that they are focused on an adult who has a more pronounced motivation for their own learning and development. This motivation is supported by a conscious choice of the area of their professional and personal development. Developing in cooperation with teachers of higher education, teachers of natural subjects, methodologists of the model of the educational process in the form of course work and theses, the student substantiates and protects them as his own author's system of activity (ASA) of the teacher of natural subjects, which guarantees the achievement of high professional results in future professional activities, the quality control criteria of which should be presented in this ASA. The student (future teacher) of natural subjects already carries out partial check, approbation of the created model of ASA during the training in high educational institution: both on seminar, practical, laboratory occupations, trainings, on consultations with teachers, etc., and in the course of active pedagogical practice. This approach to the preparation of a competitive teacher of natural science subjects with university education contributes to the formation of its general and professional competencies. The formation of professional competence of a specialist is one of the main goals of training a teacher of natural subjects. An achieving of this goal requires the development and application of appropriate acmeological technology of teaching in high pedagogical school which can be implemented as a result of the integration of three factors: concentration, problem and contextuality. The concentration is aimed at ensuring the mobility of communication in the structure of professional competence of the specialist, the problem is primarily focused on the development of his critical thinking, and the problem in combination with the context provides flexibility in the application of methods of professional activity. For A. Verbitsky context training is a conceptual basis for the integration of educational, scientific and practical activities of students $^{18}$. Highlighting the educational activities of the academic type, quasiprofessional and educational activities as the main organizational forms

17 Энциклопедия профессионального образования: В 3- х т. / Под ред. С. Я. Баты-шева. Москва : АПО, 1998. Т. 1. А-Л. С. 25.

18 Вербицкий А. А., Дубовицкая Т. Д. Контексты содержания образования. Москва : РИЦ МГОПУ им. М. А. Шолохова, 2003. 80 с.; Вербицкий А. А. Активное обучение в высшей школе: контекстный подход: Метод. пособие. Москва: Высшая школа, 1991. 207 с. 
of contextual learning, he emphasizes the special role in contextual learning the active forms and methods of learning. The specifics of contextual learning technology reflect the following basic principles of its construction.

1. The principle of concentration follows from the requirements of the theory of concentration of educational information. According to this principle, it is necessary to take into account a number of psychological and pedagogical laws: 1) the training material of a large volume is difficult to remember; 2) the training material, compactly located in a certain system, facilitates perception; 3) the allocation of the material that is studied, semantic reference points contributes to the effectiveness of its memorization. The requirements of these laws should not run counter to the principles of science and functionality and thus violate the logic of the subject. The principle of concentration is provided by appropriate structuring of educational information.

2. The principle of motivation based on modelling of professional activity is dominant. It is aimed at stimulating educational and cognitive activity. This motivation is one of the leading links of fraudulent synthesis in the architecture of the functional system of educational activity of students at this stage of training. In the structure of the problem module to ensure this principle are two blocks: input and problem.

3. The principle of the problem reflects the requirements of didactic regularity, according to which the introduction of such stimulating links as the problem situation and practical orientation increases the efficiency of learning. This principle is implemented in the formulation and solution of major problems, as well as it is the source for the construction of the logic of the problem module and its elements, in particular in the construction of elements of the author's system of professional activity of the student. The requirements of the problem principle are reflected in almost all stages of application of acmeological technologies of professional training of future teachers to the using of innovative technologies of teaching natural subjects.

4. The principle of visualization is a consequence of the pedagogical regularity, according to which the effectiveness of assimilation increases, if the visibility in training performs not only illustrative, but also cognitive function. The importance of this principle is emphasized by the presence of two aspects of its 
application: on the one hand, direct cognitive visualization is a necessary component of the technologization of the educational process by teachers of natural subjects in secondary education, on the other hand, there is the need for special training of students to implement this principle in a professional environment. This principle has particular importance in the information and educational environment.

5. The principle of cognitive dissonance is aimed at systematic creation of a situation in the process of learning to find errors. The requirements of this principle are reflected at different stages of training. This principle is also aimed at the development of didactic materials and tools aimed at the formation of the apparatus of activity of those who study. The role of the principle of cognitive dissonance is to focus learning on the formation of critical thinking which is an integral component of professional competence.

6. The principle of unity of integration and differentiation involves the processes of integration, interpenetration and synthesis of various educational components and at the same time different levels of differentiation in the study of these components by students ${ }^{19}$.

The construction of the process of training the future teacher of natural subjects on the problem-context basis, the systematic application of these didactic principles allows:

- to implement the focus on the formation of knowledge mobility, flexibility of the method and critical thinking of the future teacher of natural subjects;

- to integrate and differentiate the content of training by grouping problem modules which will ensure the development of the course in full, shortened and in-depth versions;

- to carry out, using the variability of the structure of the problem module, the independent choice of the course options by students depending on the level of training and to provide an individual rate of progress in the program;

- to use problem modules as scenarios for the creation of pedagogical software;

- to emphasize the work of the teacher on the consultative and coordinating functions of management of cognitive activity of students;

19 Козловська I. М. Теоретико-методологічні аспекти інтеграції знань учнів професійно-технічної школи: дидактичні основи. Монографія / За ред. С. У. Гончаренка. Львів : Світ, 1999. 302 с. 
- to apply an effective system of rating control and evaluation of students ' learning.

As noted by E. A. Klimov ${ }^{20}$, from a psychological point of view, a reasonable tactic in the teacher-student relationship (including the student's attitude to himself) should be that when calculating the educational trajectory of the future teacher of natural subjects, we take into account possible typical variants of contradictions that can give rise to a situation of acute crisis. During the preparing a future teacher of natural subjects for the development and using of modern teaching technologies in secondary school, the following variants of contradictions can be identified.

A. The contradiction between the characteristics of a particular student - the future teacher of natural subjects and the educational environment:

a) the situation of competition between students at the undergraduate level and the underdeveloped ability or desire of the student to get a future profession and make informed professional choices in a timely manner;

b) between the situation of the usual status of the student as a subject of learning, and the need for psychological reorientation to the role of the one who teaches - the teacher of natural science subjects (for most students this contradiction is the most tangible and requires significant efforts to overcome it. For some students the help from teachers, involvement in contextual training is extremely necessary);

c) between the high demands made by the profession of a teacher of natural subjects and knowing his own low technological level.

B. The contradictions within the structure of the future teacher of natural subjects as a subject of training: a) in the structure of technological competence:

- between a technological competence and social (he knows invariants of professional activity of the teacher of natural subjects, is able to design educational process on natural science subjects, but badly, incorrectly understands people - teachers, students, pupils; unsuccessfully builds with them the relations; isn't focused in questions of social psychology, isn't interested in them);

${ }^{20}$ Климов Е. А. Основы психологии: Учебник для вузов. Москва : Культура и спорт, ЮНИТИ, 1997. 295 с. 
- between one-sided technological competence and social (giving importance to his mental states, experiences, the student poorly imagines the inner world of students, attributing them to their possible states and taking without noticeable criticism for the truth that he will come to mind; all this happens unconsciously, unwittingly, and therefore the student can be sincerely convinced of the correctness of his thoughts about others, without subjecting them to revision);

- between the uneven development of student individual skills, actions related to technologization of the educational process, with its invariant, general and technological training (some of the invariants can be learned very well, causing the student based on individual success the illusion of his high technological success; however, in general, the system invariants and nanotechnology learned worse later make themselves known);

b) in the structure of personal values of the future teacher of natural subjects, his "value" orientations:

- between the orientation "on learning" and "learning in itself" focus on the "show" itself as a technological sample, can too dominate whereas the real level of pedagogical skills and the impact as teacher of natural subjects can little worry, because the true causes are not too high success may see in a wrong way; as a consequence there is a reduction in work, slowing of technological formation;

- between a focus on self-development and self-preservationsetting on self-development can cause excessive stress, fatigue and neurotic conditions which will cause reduction of efficiency);

- between a business focus on the specialization of a physicist and a teacher of natural subjects;

c) in the structure of the future teacher of natural subjects as a subject of activity:

- between the pace of development of motivational and operational components of technological activities (the student hasn't mastered even a single nvariant and nanotechnology learning natural subjects yet, and already wants to "grab the stars", takes on a creative function and results in a high probability of failure with attendant worries and lack of faith in themselves and in their technological abilities);

- between the processes of development and compensation of personal qualities that contribute to or hinder the successful application of elements of technology (awareness or not, the use or not of their strong qualities and, accordingly, overcoming or ignoring the weak). 
The using of acmeological technologies of training of future teachers of natural subjects shows that most of these contradictions are solved or partially removed provided the contextuality of training of students, with the consistent development of the author's system of activity by each student and testing in the real conditions of teaching natural subjects in secondary school. However, the using of these technologies is variable and has its own characteristics.

\section{CONCLUSIONS}

The formation of general and professional competencies of these competencies is based on the study of the features of the process of teaching natural subjects as a link in the pedagogical process, teaching its construction and setting in motion. The main uniting semantic core of professional training of teachers of natural subjects is chosen design and application of technologies of training by students.

Generalized invariant actions of the teachers of natural subjects selected. It which is a sequence of seven steps that are required in any learning technology natural science subjects, such as scientificmethodical analysis of materials; goal-setting; a modelling activities of teachers and students; the design of the system of teaching materials; planning of an educational experiment; planning to work with educational tasks; construction of a technological line of studying the topic. The cognitive model of design and choice of technologies of teaching natural subjects, implementing the theoretical provisions, postulating the presence at the base of any decision on the design or using of technologies of teaching natural subjects three fundamental cognitive blocks: inherent to the teacher "Scientific model of the world", his ideas about his "Means" and "Indicative basis of activity", is constructed.

The possible typical variants of contradictions that can create a situation of acute crisis in the process of training future teachers of natural subjects are identified and the ways to overcome them by means of acmeological approach are outlined.

Acmeological approach to the formation of professional competencies of future teachers of natural science subjects is that developing in cooperation with teachers of higher education, teachers of natural subjects, methodologists of the model of the educational process in the form of course and qualifying works, the student substantiates and protects them as his own author's system of activity 
(ASD) teachers of natural subjects, which guarantees the achievement of high professional results in future professional activities. The student (future teacher) of natural subjects carries out partial check, approbation of the created model of ASD already during training in high educational institution: both on seminar, practical, laboratory occupations, trainings, on consultations with teachers, etc., and in the course of active pedagogical practice. This approach to the preparation of a competitive teacher of natural science subjects with university education contributes to the formation of its general and professional competencies.

\section{SUMMARY}

The study considers general common approaches and features of professional training of future teachers of natural subjects. The main uniting semantic core of professional training of teachers of natural subjects is chosen design and application of technologies of training by students. The generalized invariant of actions of the teacher of natural subjects is allocated. The cognitive model of design and choice of technologies of natural subjects teaching is constructed. The acmeological approach to the formation of professional competences of future teachers of natural subjects is concretized.

\section{REFERENCES}

1. Атаманчук П. С. Інноваційні технології управління навчанням фізики. Кам'янець-Подільський : К-ПДПУ, 1999. 174 с.

2. Беспалько В. П. Слагаемые педагогической технологи. Москва : Педагогика, 1989. 302 с.

3. Вербицкий А. А., Дубовицкая Т. Д. Контексты содержания образования. Москва : РИЦ МГОПУ им. М. А. Шолохова, 2003. 80 с.

4. Вербицкий А. А. Активное обучение в высшей школе: контекстный подход: Метод. пособие. Москва : Высшая школа, 1991.207 c.

5. Деркач А. А., Кузьмина Н. В. Акмеология: пути достижения вершин профессионализма. Москва : Просвещение, 1993. 188 с.

6. Іваницький О. I. Сучасні технології навчання фізики у середній школі. Монографія. Запоріжжя : Прем'єр, 2001. 266 с.

7. Іваницький О. І. Інноваційні технології навчання фізики. Навчальний посібник. Запоріжжя : Диво, 2007. 99 с. 
8. Іваницький О. І., Ткаченко С. П. Технології навчання фізики. Навчальний посібник. Запоріжжя : ЗНУ, 2010. 252 с.

9. Іваницький О. I. Професійна підготовка майбутнього вчителя фізики в умовах інформаційно-освітнього середовища. Запоріжжя : Запорізький національний університет, 2014. 230 с.

10. Іваницький O. I. Формування фахових компетентностей майбутніх учителів фізики в процесі самостійної роботи. Вісник Запорізького національного університету. Педагогічні науки. Вип. 1 (30). Запоріжжя : ЗНУ, 2018. С. 107-113.

11. Ішмуратов А. Т. Конфлікт і згода. Основи когнітивної теорії конфліктів. Київ : Наукова думка, 1996. 190 с.

12. Климов Е. А. Основы психологии: Учебник для вузов. Москва : Культура и спорт, ЮНИТИ, 1997. 295 с.

13. Козловська I. M. Теоретико-методологічні аспекти інтеграції знань учнів професійно-технічної школи: дидактичні основи. Монографія / За ред. С. У. Гончаренка. Львів : Світ, 1999. $302 \mathrm{c.}$

14. Кузьмина Н. В. Предмет акмеологии. Санкт-Петербург : Питер, 1995. 158 с.

15. Российская педагогическая энциклопедия: В 2 тт. / Гл. ред. В. В. Давыдов. Москва : Большая Российская Энциклопедия, 1998. 672 с. Т. 2. М-Я.

16. Сергеев В. М., Цыбульский В. Л. Когнитивные механизмы принятия решений: Модель и приложения в политологии и истории. Компьютеры и познание. Москва, 1990. С. 105-124.

17. Справочник учителя физики. Приложение к сборнику «Проблемы формирования теоретических обобщений и вариативных технологий обучения физике». Вып. 1. Москва : МПУ, $1999.59 \mathrm{c}$.

18. Энциклопедия профессионального образования: В 3-х т. / Под ред. С. Я. Батышева. Москва : АПО, 1998. 568 с. Т. 1. А-Л.

\section{Information about the author: Ivanytsky $O$. I.}

Doctor of Educational Sciences, Professor,

Zaporizhzhia National University 66, Zhukovsky str., Zaporizhzhia, 69000, Ukraine 